\title{
Factors affecting survival of test bacteria in sea water: marine bacteria, test bacteria and solid surfaces
}

\author{
K. Moebus \\ Biologische Anstalt Helgoland (Meeresstation); \\ Helgoland, Federal Republic of Germany
}

\begin{abstract}
KURZFASSUNG: Faktoren, welche das Überleben von Testbalterien in Meerwasser beeinflussen: Meeresbakterien, Testbakterien und feste Oberflächen. Der Einfluß der vorstehend genannten Faktoren wurde auf die Überlebensfähigkeit von Escbericbia coli, Stapbylococcus aureus und Serratia marinorubra in Meerwasser untersucht. Aktivitäten mariner Bakterien führten nicht generell zu verstärkter antibakterieller Wirkung rohen Meerwassers. Häufig waren sie für das Überleben von $E$. coli und $S$, aureus förderlich. Inaktivierte Zellen von $E$. coli und $S$. aureus erhöhten die bakterizide Wirkung rohen und filtersterilisierten Meerwassers gegenüber sekundär inokulierten, gleichartigen Testbakterien, während sie die inakrivierende Potenz autoklavierten Meerwassers verminderten. Durch erhöhtes Angebot an Glasoberfläche/Volumeneinheit, welches die adsorptive Anreicherung organischer Substanzen verstärkt, wurde die Inaktivation von $E$. coli und $S$. aureus meistens beschleunigt, während sich diejenige von S. marinorubra um so stärker verminderte, je größer das Verhältnis Oberfläche/Volumen war. Raschere Abtötung von $E$. coli und $S$. aureus in Sterilfiltraten als in rohem Meerwasser trat bei erhöhtem Oberfläche/Volumen-Verhältnis häufiger auf als unter Standardbedingungen. Aus den Ergebnissen wird geschlossen, daß die während der Versuche eintretenden Veränderungen des Nährstoffangebotes, hervorgerufen durch Nährstoffverbrauch sowie durch Lysis inaktivierter Testbakterien, bezüglich der bakteriziden Wirkung von Meerwasser generell von größerer Bedeutung sind als bakterizide Stoffwechselprodukte mariner Bakterien.
\end{abstract}

\section{INTRODUCTION}

Since DE GIAXA's (1889) investigation, marine bacteria are known to play an important role in regard to the inactivation of non-marine bacteria in sea water under laboratory conditions. Generally, negative effects of indigenous bacteria on the survival of test bacteria were observed. For example, it was reported by Кетснuм et al. (1949) that second inocula of Escherichia coli in raw sea water were more rapidly inactivated than first ones. At least in part, this must be attributed to activities of marine bacteria exhibited during incubation of first inocula. These activities are thought mainly to be restricted to competitive food consumption and to excretion of harmful metabolic by-products (VACCARo et al. 1950). Consumption of nutrients, in any case, takes place during growth of marine bacteria. Changes in the natural nutrient concentration of sea water, caused by bacterial activities, probably affect to a considerable degree the 
ability of test bacteria to survice (Moesus 1972b). Therefore, it is very difficult to assess the extent to which competitive food consumption alone or in combination with inimical compound release is responsible for test bacterial kill, unless the presence of harmful matter - and also its activity - can be established otherwise (e.g. by agar-well tests).

Competition for nutrients between marine and test bacteria has received critical attention by Carlucci \& Pramer (1960) and Moebus (1972a, b). However, results were obtained from sea water enriched with unnaturally high concentrations of organic matter, or they refer to Serratia marinorubra (MoEBus 1972a) which was isolated from the sea by ZoBell \&. UPHAM (1944). Although this strain has been maintained on nutrient-rich media for many years it still reveals potencies which distinguish it from strictly non-marine bacteria. Therefore, the observations made are of limited value with respect to competition for nutrients occurring between marine and non-marine bacteria at food levels normally present in sea water.

Isolation of marine bacteria capable of producing antibiotic-like substances has been reported by Rosenfeld \& ZoBell (1947), Grein \& Meyers (1958), KrasiLnikova (1961), BaAm et al. (1966), Gauthier (1969) and others. Production of inhibitory matter was found to depend on the media used; it was most effective in the presence of high nutrient concentrations. Furthermore, the studies were performed with pure cultures of marine bacteria. Our present knowledge on synthesis of harmful compounds by natural populations of marine bacteria in unsupplemented sea water is rather speculative.

Growth of marine bacteria in unsupplemented sea water under laboratory conditions tends to increase as a function of solid surface area available per unit water volume (ZOBELL \& ANDERSON 1936). This growth-promoting effect is assumed to be due to adsorptive concentration of organic nutrients on solid surfaces. This assumption of ZoBell \& ANDERSon was later confirmed by STARK et al. (1938) and ZoBell (1943). The growth-promoting effect of solid surfaces at limiting nutrient concentrations was also observed in Escherichia coli by HeUkELEKIAN \& HeLLer (1940). In regard to the influence of solid surfaces on the inactivation of test bacteria in sea water no information is available from the literature.

Examination of solid surface effects on marine bacterial growth and test bacterial kill, as well as experiments with repeatedly inoculated sea water, are hoped to provide a clue for acquiring insights into the mechanism(s) by which marine bacteria affect the survival of test bacteria in sea water.

\section{MATERIALS AND METHODS}

Fundamental aspects of the materials and methods used during this investigation have been described by Moebus (1972a, b). Sea water was always sampled at station "Kabeltonne" in the channel between. Helgoland and its adjacent dune (Southern North Sea). In order to obtain different surface/volume ratios, two methods were employed: (1) Sea water samples of $26 \mathrm{ml}$ in culture flasks $(5 \mathrm{~cm}$ in diameter, $200 \mathrm{ml}$ in volume), or of $10 \mathrm{ml}$ in culture tubes (18 $\mathrm{mm}$ in diameter), were used; in the tubes, 
the surface/volume ratio was about 1.75 times greater than in the flasks. (2) Parallel $26 \mathrm{ml}$-sea water samples were tested in culture flasks, one of which contained 30 pieces of glass tubing ( $1 \mathrm{~cm}$ in length, $6 / 4 \mathrm{~mm}$ in outer/inner diameter); glass tubing increased the surface/volume ratio by the factor 3.56. In general, results are presented as $\log \left(\mathrm{N}_{\mathrm{x}}-\mathrm{N}_{0}\right)$ values, where $\mathrm{N}$ is the number of colony-forming bacteria/ml established after 0 and $x$ days of incubation at $25^{\circ} \mathrm{C}$ in the dark, respectively. Additional information is provided in the section "Results".

\section{RESULTS}

A series of experiments was conducted with $100 \mathrm{ml}$-samples of differently treated sea water, filled into $300 \mathrm{ml}$-Erlenmeyer flasks and inoculated several times to about $10^{7}$ cells/ml of test bacteria. Figure 1 presents inactivation curves established from raw sea water ( $r s w)$ for 6 successive inocula of Escherichia coli, Staphylococcus aureus and Serratia marinorubra (sections A, B and C, respectively). With each test strain, the most striking differences between the individual inactivation curves were found for inocula 1 to 4 .

Inactivation of the second inocula of Escherichia coli and Serratia marinorubra was, within the first 2 days of incubation, faster than that of first ones. After 4 days, however, for both test strains nearly identical portions of survivors were found from both inocula. Regarding S. marinorubra, the same holds true for the third inoculum. Contrasting findings were obtained for Staphylococcus aureus during this experiment. In comparison with the first inoculum, inactivation of the second one was greatly delayed. (Since this result was not expected, platings were performed from insufficiently diluted suspensions after 2 days of incubation. Therefore, the number of colonies/agar plate was too great to be accurately countable, and no exact $\log \left[\mathrm{N}_{2}-\mathrm{N}_{0}\right]$ value could be determined as indicated by the broken line in Figure 1.) During incubation of the second $S$, aurens inoculum, however, conditions were attained which caused rapid kill of the third one at a rate nearly constant throughout its incubation as was observed for the second inoculum of $E$. coli.

The number of marine bacteria/ml during this experiment (Fig. 1), after initial increase, remained fairly constant. During long-term incubation of rsw - whether noninoculated, or inoculated once with test bacteria - initial increase of bacterial number/ $\mathrm{ml}$ is usually followed by a pronounced decrease. The latter failed to occur during the present experiment. Formation of marine bacterial colonies on 2216E-agar is hindered to some extent by Serratia marinorubra as long as the number of viable cells $/ \mathrm{m} 1$ of this strain considerably exceeds that of marine bacteria. Therefore, the reduced marine bacterial number $/ \mathrm{ml}$, sometimes established after one day of incubation of successive inocula of $S$. marinorubra in rsw, is assumed to be due to repression of colony formation but not due to a real decrease in bacterial titer. (The same holds true for some findings presented in Table 1.) Note: To determine the number of marine bacteria $/ \mathrm{ml}$ present at the end of each incubation period platings were performed prior to reinoculation. 

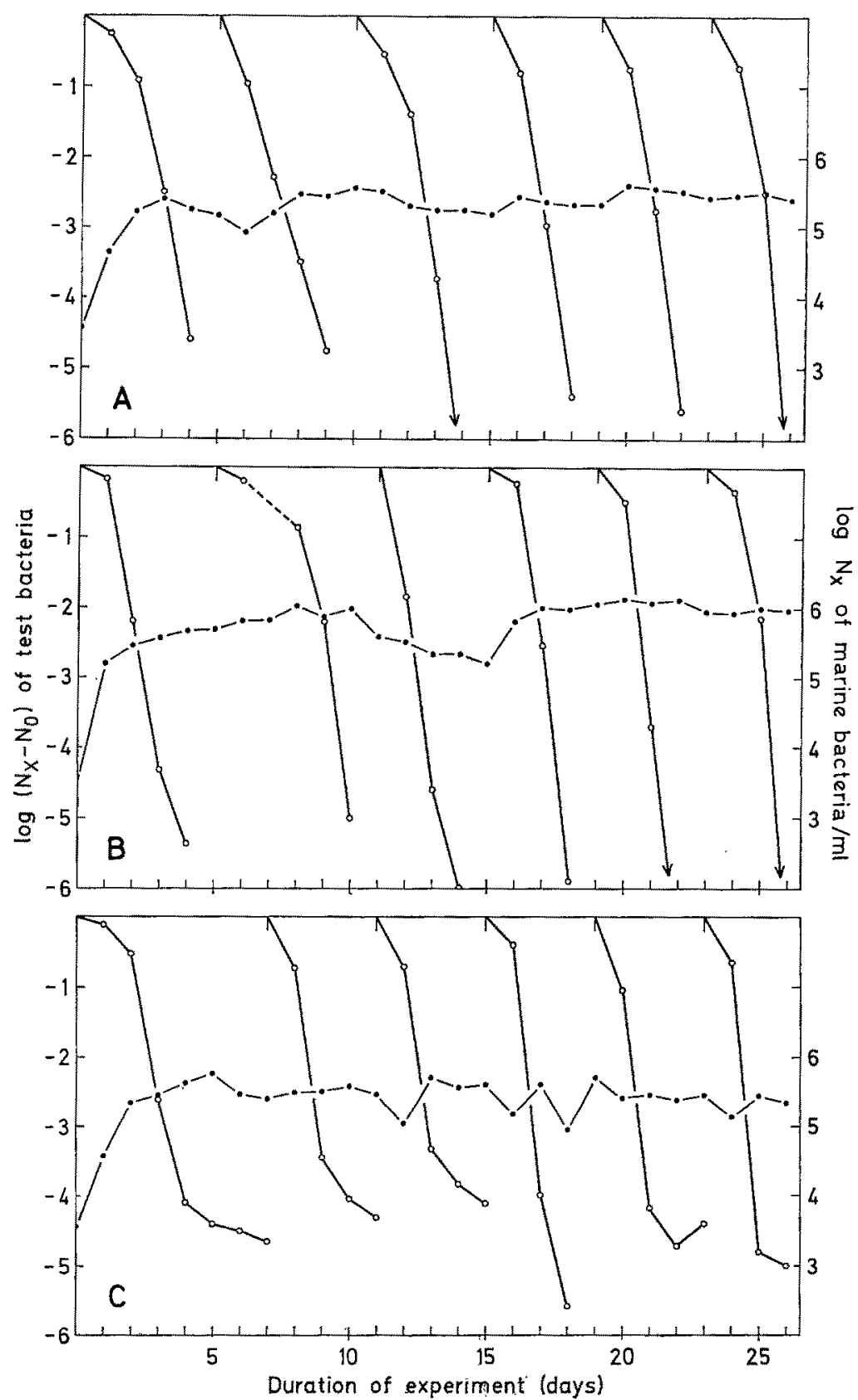

Fig. 1: Eschericbia coli, Staphylococcus aureus, and Serratia marinorubra (sections A, B, C). Inactivation curves established for 6 successive inocula of test bacteria $(O)$ during incubation in raw sea water at $25^{\circ} \mathrm{C}$ in the dark. Samples of initially $100 \mathrm{ml}$ were inoculated to about $10^{7} \mathrm{cells} / \mathrm{ml}$ of test bacteria. : Colony-forming marine bacteria 
The dominant role of harmful marine bacterial excretes in causing variations in antibacterial activity of $r s w$ during tests is questioned by the results obtained for inocula 1 to 3 incubated in this medium (Fig. 1). The doubts are supported by ob-

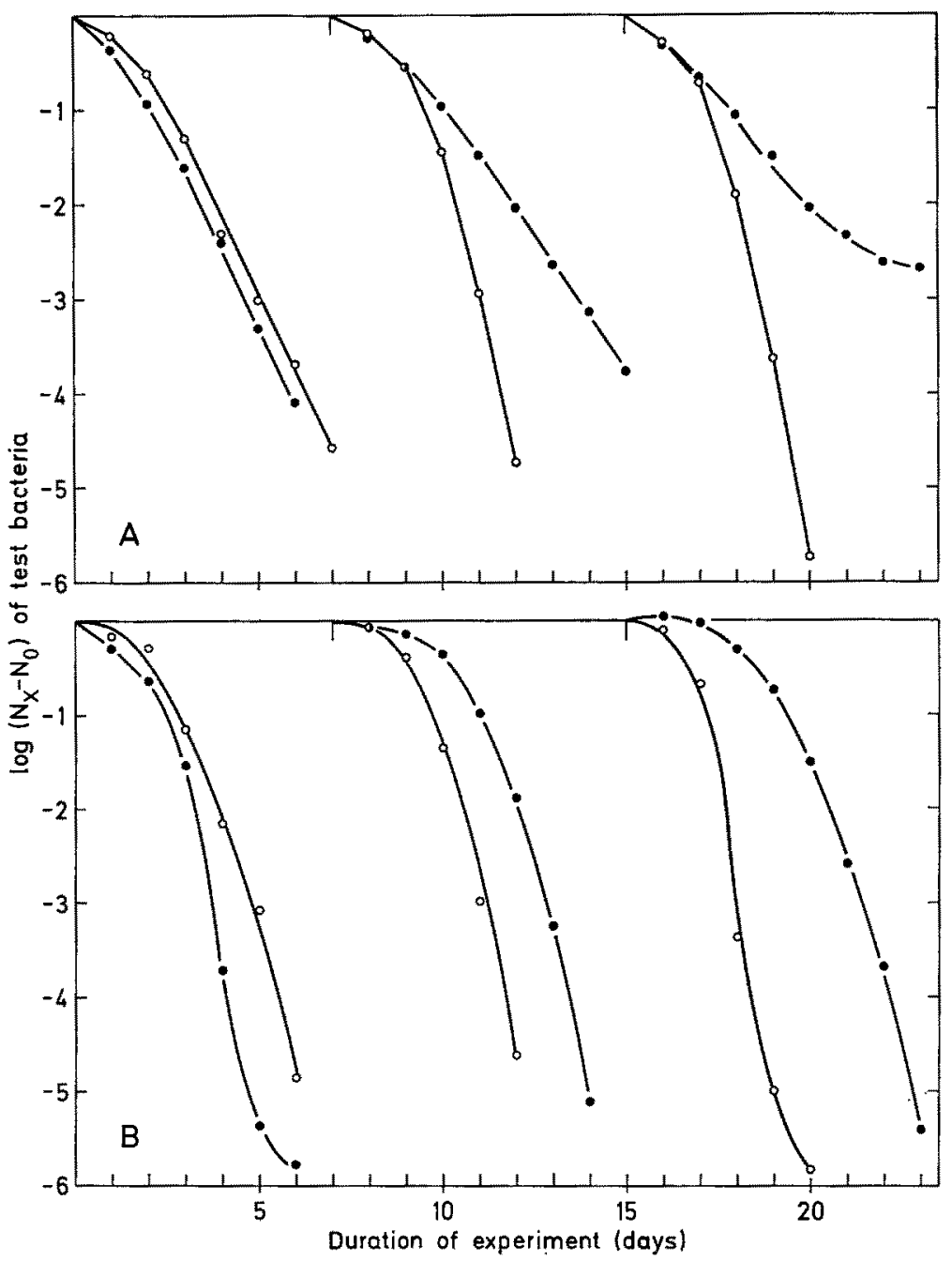

Fig. 2: Escherichia coli and Staphylococcus aureus (sections A and B). Inactivation curves for 3 successive inocula of test bacteria incubated in filter-sterilized (O) and in autoclaved ( ) sea water. (Other data as in legend to Fig. 1)

servations made from filter-sterilized sea water $(f s w)$ during the same experiment. As can be seen from Figure 2 (sections A and B refer to Escherichia coli and Staphylococcus aureus, respectively), increased bactericidal activity of $f_{s w}$ occurred after inactivation of first as well as of second inocula of these test strains. Such response must be due to effects exerted by the test bacteria themselves. 
Table 1

Antibacterial activity of raw sea water as influenced by presence or absence of test bacteria during pre-incubation at $25^{\circ} \mathrm{C}$ in the dark; $\log \left(\mathrm{N}_{\mathrm{x}}-\mathrm{N}_{0}\right)$ yalues. Italics; colony-forming marine bacteria $\left(5.2 \times 10^{2} / \mathrm{ml}\right.$ at beginning of experiment)

\begin{tabular}{|c|c|c|c|c|c|c|}
\hline \multicolumn{7}{|c|}{ (A) Pre-incubation of $35 \mathrm{ml}$-samples } \\
\hline \multirow{2}{*}{$\begin{array}{l}\text { Period of } \\
\text { incubation } \\
\text { (days) }\end{array}$} & \multicolumn{3}{|c|}{ Samples inoculated with } & \multicolumn{3}{|c|}{ Parallel samples not inoculated } \\
\hline & E. coli & S. aureus & norubra & $I$ & II & III \\
\hline 2 & $-\frac{1.56}{2.51}$ & $\begin{array}{r}-1.76 \\
2.53\end{array}$ & $\begin{array}{r}-1.70 \\
2.54\end{array}$ & 2.39 & 2.09 & 2.30 \\
\hline 3 & -2.17 & -1.16 & -1.13 & 2.78 & 2.49 & 2.77 \\
\hline 4 & $\begin{array}{r}-5.37 \\
2.88\end{array}$ & -4.34 & $\begin{array}{r}-2.76 \\
3.04\end{array}$ & 2.81 & 2.58 & 2.82 \\
\hline \multicolumn{7}{|c|}{$\begin{array}{l}\text { (B) Second inocula of test bacteria during incubation of } 25 \mathrm{ml} \text {-subsamples in flasks or } \\
\qquad 7 \mathrm{ml} \text {-subsamples in tubes }\end{array}$} \\
\hline \multirow{2}{*}{$\begin{array}{c}\text { Period of } \\
\text { incubation } \\
\text { (days) }\end{array}$} & \multicolumn{6}{|c|}{ Subsamples re-inoculated with } \\
\hline & $25 \mathrm{ml}$ & $7 \mathrm{ml}$ & $25 \mathrm{ml}$ & $7 \mathrm{ml}$ & $25 \mathrm{ml}$ & $7 \mathrm{ml}$ \\
\hline 1 & $\begin{array}{r}-1.05 \\
2.70\end{array}$ & $\begin{array}{r}-2.35 \\
2.60\end{array}$ & $\begin{array}{r}-2.21 \\
2.90\end{array}$ & $\begin{array}{r}-3.99 \\
2.90\end{array}$ & $\begin{array}{r}-2.47 \\
3.27\end{array}$ & $\begin{array}{r}-1.49 \\
3.19\end{array}$ \\
\hline 2 & $\begin{array}{r}-5.00 \\
2.82\end{array}$ & $\leq 6$ & $\begin{array}{r}-5.83 \\
2.90\end{array}$ & $\begin{array}{r}-5.05 \\
2.79\end{array}$ & $\begin{array}{r}-4.52 \\
3.22\end{array}$ & $\begin{array}{r}-4.56 \\
3.14\end{array}$ \\
\hline 3 & $\begin{array}{l}\leq 6 \\
3.19\end{array}$ & $\overline{2.93}$ & $\begin{array}{r}-5.76 \\
3.19\end{array}$ & $\begin{array}{r}-6.70 \\
2.74\end{array}$ & $\begin{array}{r}-4.67 \\
3.18\end{array}$ & $\begin{array}{r}-5.84 \\
2.94\end{array}$ \\
\hline \multicolumn{7}{|c|}{ (C) $7 \mathrm{ml}$-subsamples of raw sea water pre-incubated without test bacteria } \\
\hline $\begin{array}{c}\text { Period of } \\
\text { incubation } \\
\text { (days) }\end{array}$ & $\begin{array}{l}\text { Subsamp } \\
\text { E. coli }\end{array}$ & $\begin{array}{l}\text { les inocula } \\
\text { S. aureus }\end{array}$ & $\begin{array}{l}\text { S. mari- } \\
\text { nornbra }\end{array}$ & & $\begin{array}{l}\text { mples der } \\
\text { pre-incub } \\
\text { sample }\end{array}$ & $\begin{array}{l}\text { ved } \\
\text { ted } \\
\end{array}$ \\
\hline 1 & $\begin{array}{r}-1.69 \\
2.56\end{array}$ & $\begin{array}{r}-1.01 \\
3.00\end{array}$ & $\begin{array}{r}-1.35 \\
2.43\end{array}$ & & \multirow{3}{*}{ I } & \\
\hline 2 & $\begin{array}{r}-2.43 \\
2.98\end{array}$ & $\begin{array}{r}-4.25 \\
3.06\end{array}$ & $\begin{array}{r}-5.80 \\
3.20\end{array}$ & & & \\
\hline 3 & $\begin{array}{r}-4.12 \\
3.03\end{array}$ & $\begin{array}{r}-6.90 \\
3.29\end{array}$ & $\leq 6$ & & & \\
\hline 1 & $\begin{array}{r}-1.79 \\
2.26\end{array}$ & $\begin{array}{r}-2.10 \\
3.05\end{array}$ & $\begin{array}{r}-1.80 \\
1.89\end{array}$ & & \multirow{3}{*}{ II } & \\
\hline 2 & $\begin{array}{r}-2.12 \\
2.71\end{array}$ & $\begin{array}{r}-3.36 \\
3.22\end{array}$ & $\begin{array}{r}-2.51 \\
2.64\end{array}$ & & & \\
\hline 3 & $\leqq 6$ & $\begin{array}{r}-5.83 \\
3.13\end{array}$ & $\begin{array}{r}-5.93 \\
2.86\end{array}$ & & & \\
\hline 1 & $\begin{array}{r}-1.81 \\
2.91\end{array}$ & $\begin{array}{r}-1.09 \\
3.19\end{array}$ & $\begin{array}{r}-1.65 \\
2.87\end{array}$ & & \multirow{3}{*}{ III } & \\
\hline 2 & $\begin{array}{r}2.77 \\
2.99\end{array}$ & $\begin{array}{r}-4.87 \\
3.12\end{array}$ & $\leq \begin{array}{r}4.2 \\
3.29\end{array}$ & & & \\
\hline 3 & $\begin{array}{r}-6.80 \\
2.89\end{array}$ & $\begin{array}{r}-5.74 \\
3.18\end{array}$ & $\leq 6$ & & & \\
\hline
\end{tabular}


In contrast to the observations made from fsw, the bactericidal capacity of autoclaved sea water (asw) gradually decreased in correlation to increasing number of inactivated cells of Eschericbia coli and Staphylococcus aureus, respectively. The results are also shown in Figure 2. Findings obtained for Serratia marinorubra are not presented since inactivation of this test strain was very weak in both media. After 26 days of incubation (of first inocula) the $\log \left(\mathrm{N}_{\mathrm{X}}-\mathrm{N}_{0}\right)$ values established from fsw and aswe were -3.61 and -2.26 , respectively.

Several observations support the assumption that the antibacterial activity of rsw likewise is influenced by (killed) test bacteria. This is demonstrated by results summarized in Table 1. The experiment was performed as follows: Samples of $35 \mathrm{ml}$ $r s w$ (in culture flasks) were inoculated with test bacteria to about $10^{7}$ cells $/ \mathrm{ml}$ or remained not inoculated ( 3 parallels). After 4 days of incubation the initially inoculated samples received test bacteria a second time. Thereupon, these samples were devided in two portions of $25 \mathrm{ml}$ and $7 \mathrm{ml}$ which were filled into culture flasks or culture tubes. Of the 3 samples remaining uninoculated for the first incubation period, 3 subsamples of $6.7 \mathrm{ml}$ each were dispensed into culture tubes. Afterwards, each series of these subsamples was inoculated with Escherichia coli, Staphylococcus aureus and Serratia marinorubra, respectively, to final volumes of $7 \mathrm{ml}$. The initial titer of test bacteria was always about $10^{7}$ cells $/ \mathrm{ml}$.

The inactivation of first inocula (part A of Table 1) was rather weak until 3 days of incubation. (At the same time considerably stronger kill in $f s w$ than in $r s w$ was found with Escherichia coli and Stapbylococcus aureus. The $\log \left(\mathrm{N}_{3}-\mathrm{N}_{0}\right)$ values established from $f$ sw were -4.05 and about -6.3 , respectively.) The kill of second inocula in $r s w$ (part B of Table 1) greatly exceeded that of first ones. The most striking findings of this experiment, however, concern inactivation observed from $7 \mathrm{ml}$-samples of rsw pre-incubated without test bacteria (part C of Table 1). Within the first 2 days of incubation, inactivation of $E$. coli and $S$. aureus in subsamples of this type was considerably weaker than in $7 \mathrm{ml}$-subsamples of $r s w$ inoculated a second time. This appears by comparison of respective $\log \left(N_{x}-N_{0}\right)$ values presented in parts $C$ and $B$ of Table 1. If bactericidal matter was produced by marine bacteria, $r s w$ pre-incubated without test bacteria should have been active similar to rsw inoculated a second time. This was established for Serratia marinorubra only. Therefore, it is assumed that the stronger anticoli and anti-staphylococcal activity of $r s w$, inoculated with respective test bacteria prior to the first incubation period, essentially is attributable to effects of these test strains themselves.

Further experiments were performed with differently sterilized samples prepared from rsw pre-incubated with test bacteria. In sterile filtrates the inactivation of test bacteria was the same as - or stronger, or weaker than - established during preceeding incubation in rsw. The findings were in no case strictly conclusive in regard to predominant effects of harmful metabolic by-products of marine bacteria. This is demonstrated by results compiled in Table 2. Samples of $150 \mathrm{ml}$ rsw (in $300 \mathrm{ml}$-Erlenmeyer flasks) were inoculated to about $10^{7}$ cells $/ \mathrm{ml}$ of test bacteria. After 4 days of incubation, portions of these samples remained untreated or were (1) filter-sterilized, (2) filtersterilized plus autoclaved, and (3) autoclaved $\left(15 \mathrm{~min}\right.$ at $\left.121^{\circ} \mathrm{C}\right)$, respectively. There- 
Table 2

Antibacterial activity of pre-incubated raw sea water ( $r s w)$ against second inocula of test bacteria, as influenced by different sterilization methods. $150 \mathrm{ml}$-samples of $r s w$ were inoculated with Escherichia coli, Staphylococcus aureus or Serratia marinorubra to about $10^{7} \mathrm{cells} / \mathrm{ml}$. After 4 days of incubation at $25^{\circ} \mathrm{C}$ in the dark, $10 \mathrm{ml}$-subsamples (trated as specified in table) were re-inoculated to about $10^{7}$ cells $/ \mathrm{ml}$ of the respective test bacteria and incubated for a second period. $\log \left(\mathrm{N}_{\mathrm{X}}-\mathrm{N}_{0}\right)$ values

\begin{tabular}{|c|c|c|c|c|c|c|c|}
\hline \multirow[b]{2}{*}{$\begin{array}{l}\text { Test } \\
\text { strain }\end{array}$} & \multicolumn{2}{|c|}{ First inocula } & \multicolumn{5}{|c|}{ Second inocula in subsamples } \\
\hline & $\begin{array}{l}\text { period of } \\
\text { incuba- } \\
\text { tion } \\
\text { (days) }\end{array}$ & $\begin{array}{l}\text { in } \\
\text { rows }\end{array}$ & $\begin{array}{c}\text { period of } \\
\text { incuba- } \\
\text { tion } \\
\text { (days) }\end{array}$ & $\begin{array}{c}\text { not } \\
\text { treated }\end{array}$ & $\begin{array}{l}\text { sterile- } \\
\text { filtered }\end{array}$ & $\begin{array}{l}\text { sterile- } \\
\text { filtered } \\
+ \\
\text { auto- } \\
\text { claved }\end{array}$ & $\begin{array}{l}\text { auto- } \\
\text { claved }\end{array}$ \\
\hline $\begin{array}{c}E \\
\text { coli }\end{array}$ & $\begin{array}{l}2 \\
3\end{array}$ & $\begin{array}{l}-2.01 \\
-5.00\end{array}$ & $\begin{array}{l}1 \\
2\end{array}$ & $\begin{array}{r}-3.45 \\
\leq 6\end{array}$ & $\begin{array}{r}-3.49 \\
\leq 6\end{array}$ & $\begin{array}{r}-1.19 \\
-3.94\end{array}$ & $\begin{array}{l}-1.57 \\
-2.33\end{array}$ \\
\hline $\begin{array}{c}S . \\
\text { aureus }\end{array}$ & $\begin{array}{l}2 \\
3\end{array}$ & $\begin{array}{l}-2.59 \\
-6.90\end{array}$ & $\begin{array}{l}1 \\
2\end{array}$ & $\begin{array}{l}-4.11 \\
-6.80\end{array}$ & $\begin{array}{l}-3.14 \\
-6.70\end{array}$ & $\begin{array}{l}-2.91 \\
-3.81\end{array}$ & $\begin{array}{l}-1.89 \\
-1.80\end{array}$ \\
\hline$\underset{\substack{S \\
\text { marino- } \\
\text { rubra }}}{ }$ & $\begin{array}{l}2 \\
3\end{array}$ & $\begin{array}{l}-1.10 \\
-4.26\end{array}$ & $\begin{array}{l}1 \\
2\end{array}$ & $\begin{array}{l}-3.40 \\
-4.23\end{array}$ & $\begin{array}{l}-1.85 \\
-1.48\end{array}$ & $\begin{array}{l}-1.98 \\
-1.88\end{array}$ & $\begin{array}{l}-1.89 \\
-1.54\end{array}$ \\
\hline
\end{tabular}

upon, the various subsamples (10 $\mathrm{ml}$ in culture tubes) again were inoculated to about $10^{7}$ cells $/ \mathrm{ml}$ of the respective test strain.

Inactivation of Escherichia coli and Stapbylococcus aureus in sterile-filtered subsamples was nearly the same as in untreated ones, whereas it was greatly reduced in all heat-treated subsamples. The latter findings point to destruction of any harmful matter during autoclaving. However, at least one further factor must have been involved in the kill of these test bacteria, since different inactivation capacities were observed from subsamples untreated and sterile-filtered prior to autoclaving, respectively. In contrast, inactivation of Serratia marinorubra in every sterilized subsample was weak.

During the experiment, the results of which are summarized in Table 1, somewhat stronger inactivation of second inocula occurred in culture tubes than in culture flasks (part B of Table 1). Similar observations were made from fsw (Moebus 1972b, Fig. 5). On the basis of such findings it is assumed that solid surfaces may affect the test bacterial kill. Tests performed with rsw at different ratios solid surface/unit volume should reveal valuable information in regard to the influence of marine bacteria on survival of test bacteria also, since marine bacterial growth in this medium is supported by solid surfaces (ZoBeLt \& ANDERson 1936). In order to examine these assumptions, rsw and $f$ sw were simultaneously tested either in flasks and tubes or in flasks in absence or presence of glass tubing.

Experiments of the first mentioned type were performed with $26 \mathrm{ml}$-samples in flasks and $10 \mathrm{ml}$-samples in tubes. Generally, the antibacterial activity of $r s w$ and fsw against Escherichia coli and Stapbylococcus aurens was stronger in tubes than in flasks. In contrast, negligible differences were found in the influence of both test conditions on the kill of Serratia marinorubra in $r s w$ and $f s w$. Growth of marine bacteria in the 
presence and absence of test bacteria was mostly somewhat stronger in tubes than in flasks. One may conclude that accelerated growth of marine bacteria accounted for more rapid inactivation of $E$. coli and $S$. aureus in rsw during incubation in tubes. This conclusion is supported by results shown in Figure 3 . These findings are unique in that nearly identical growth of marine bacteria was established from all $r s w$ samples. In

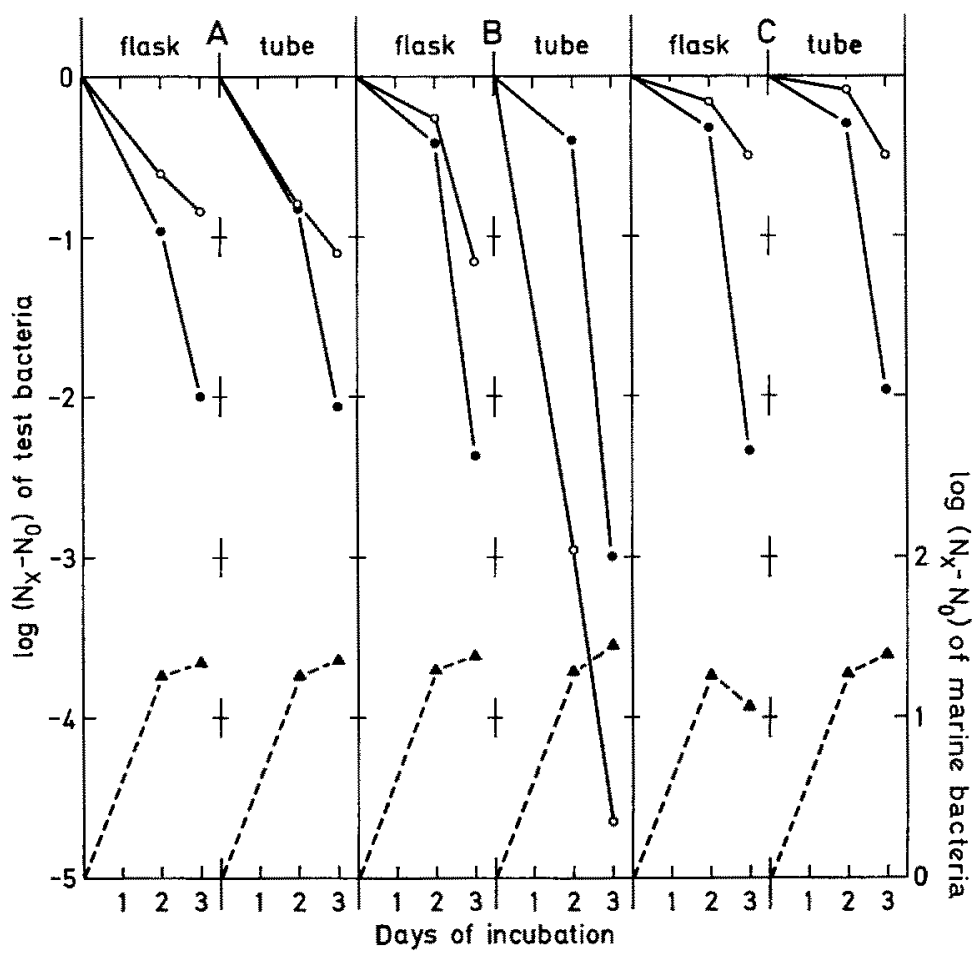

Fig. 3: Eschericbia coli, Staphylococcus aureus, and Serratia marinorubra (sections A, B, C). Inactivation of test bacteria in raw ( $)$ and in filter-sterilized $(O)$ sea water during incubation in flasks ( $26 \mathrm{ml}$-samples) and tubes (10 ml-samples) at $25^{\circ} \mathrm{C}$ in the dark. Initial cell numbers of test bacteria were about $10^{7} / \mathrm{ml}$. $\boldsymbol{\Lambda}$ : Growth of marine bacteria refers to $1.1 \times 10^{4}$ colonyformers/ml initially present

agkeement with this observation only the inactivation of $S$. aureus in rsw was somewhat different under the two test conditions. On the other hand, however, the survival of test bacteria repeatedly was affected beneficially by accelerated growth of marine bacteria. As demonstrated in Figure 4, stronger inactivation in fsw than in rsw was found for E. coli from tubes and for $S$. aureus from flasks and tubes.

During further experiments, the influence of solid surfaces was examined by adding 30 pieces of glass tubing to $26 \mathrm{ml}$-samples in culture flasks. In this way a greater increase of the surface/volume ratio was attained than by the use of tubes. Typical results of such tests are presented in Figure 5. Generally, the inactivation of Escherichia coli and Stapbylococcus aureus in rsw and fsw was considerably stronger in the pres- 


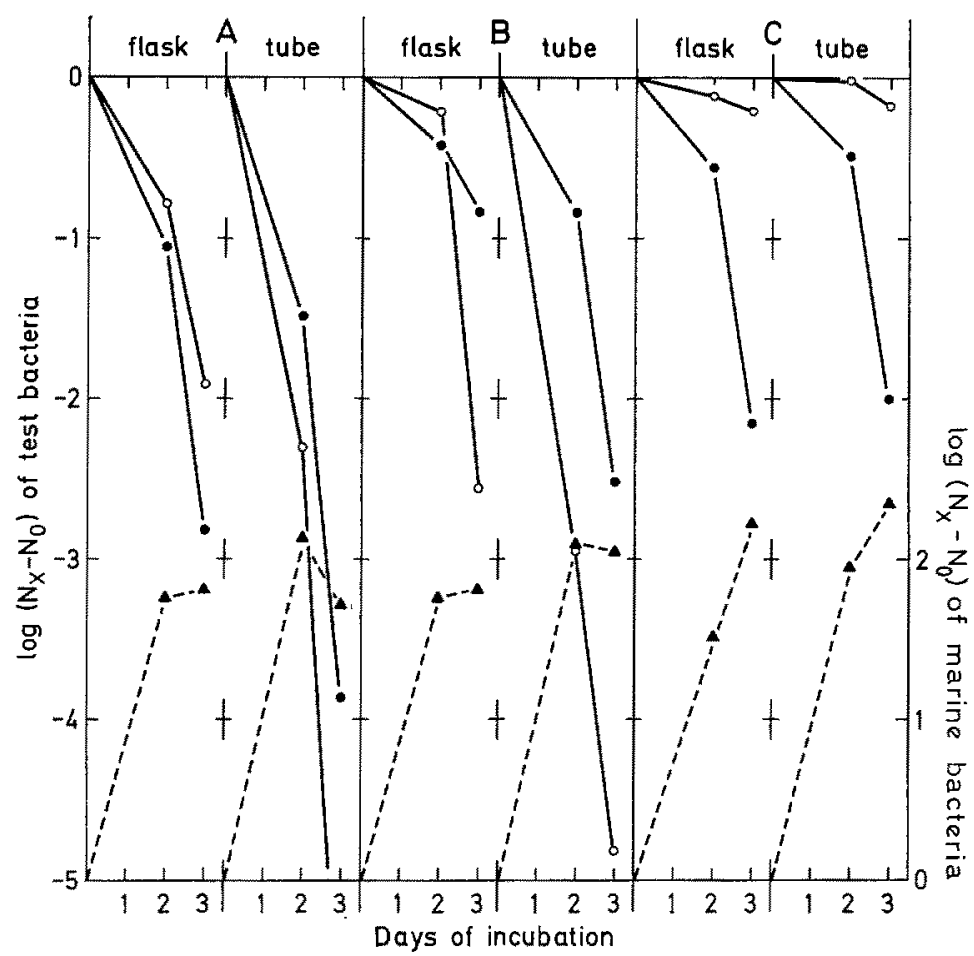

Fig. 4: Escherichia coli, Stapbylococcus aureus, and Serratia marinorubra (sections A, B, C). Inactivation of test bacteria in raw $(0)$ and in filter-sterilized $(O)$ sea water. $\mathbf{\Delta}$ : Growth of marine bacteria refers to $4.4 \times 10^{3}$ colony-formers/ml initially present. (Other data as in Fig. 3)

ence than in the absence of glass tubing. However, with $S$. aureus also opposite results were obtained from $f s w$. The kill of Serratia marinorubra in rsw was always weaker at enlarged surface/volume ratios, whereas no solid-surface effect was observed from fsw samples. Growth of marine bacteria at any rate was intensified to a considerable degree in the presence of glass tubing.

\section{DISCUSSION}

The antibacterial activity of sea water is attributed to an appreciable extent to the presence of harmful substances produced by various marine organisms, among which planktonic algae probably are most important (AUBERT et al. 1968, SiEbURTH 1968). On the other hand, it was demonstrated by Morbus (1972b) that the test bacterial kill also depends on the nutrient concentration of sea water. It varies greatly at different food levels below about $10^{-4} \mathrm{mg} / \mathrm{ml}$. Therefore, the question arises whether the variations in antibacterial activity of sea water occurring during the tests performed under laboratory conditions, as described in the present paper, are caused by 


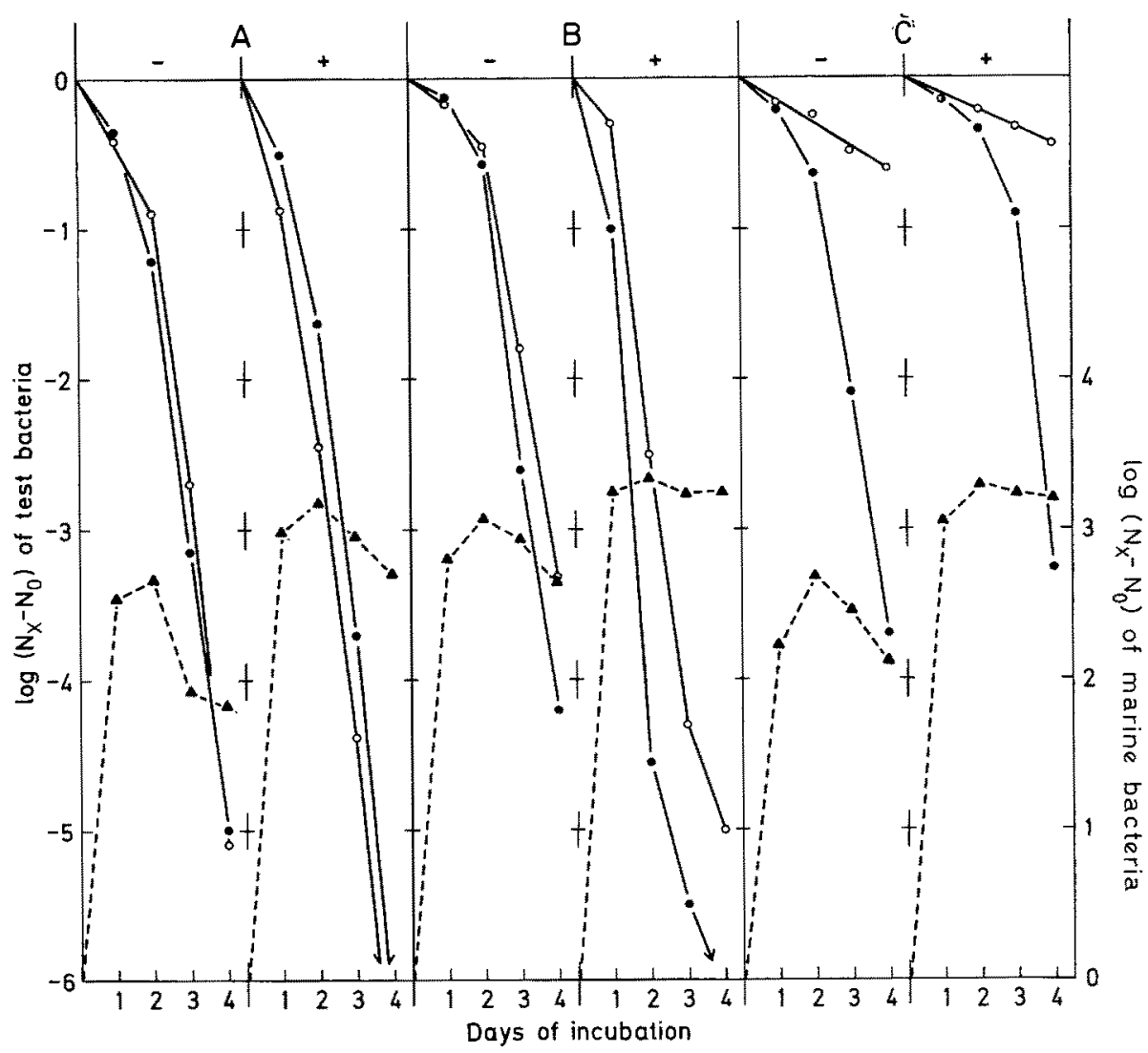

Fig. 5: Eschericbia coli, Stapbylococcus aureus, and Serratia marinorubra (sections A, B, C). Inactivation of test bacteria in raw $(-)$ and in filter-sterilized $(O)$ sea water in absence $(-)$ or presence $(t)$ of 30 pieces of glass tubing. $26 \mathrm{ml}$-samples were incubated in culture flasks at $25^{\circ} \mathrm{C}$ in the dark. Initial cell numbers of test bacteria were about $107 / \mathrm{ml}$. $\mathbf{A}$ : Growth of marine bacteria refers to $6.2 \times 10^{2}$ colony-formers $/ \mathrm{ml}$ initially present

additional release of harmful matter from dead and viable marine organisms, and/or by changes in the nutritive conditions.

The importance of bactericides released by naturally occurring phytoplankton communities during the tests is questioned by recently published results (Moesus 1972 c). It was reported that enrichment of sea water with dead or viable plankton resulted rarely in increased, but frequently in decreased inactivation of test bacteria. In general, the antibacterial activity of sea water was most effectively reduced by plankton enrichment at times of maximum bactericidal efficacy of untreated rsw. According to these results it seems reasonable to assume that variations in bactericidal capacity of $r s w$ occuring during the tests are caused primarily by activities of marine bacterial populations. These activities may involve excretion of harmful metabolic byproducts as well as competitive food consumption. 
Several findings obtained during the present investigation indicate that growth of marine bacteria, even if accelerated by solid-surface effects, does not cause increased kill of test bacteria as a general principle. Such results throw doubt on the predominant role of inimical marine bacterial excretes. The doubts are supported by the observation of anticoli and anti-staphylococcal activity of $f_{s w}$ which increased after inactivation of respective test bacteria in this medium (Fig. 2).

In sterile sea water, it is to be expected that harmful biogenic matter present before inoculation is used up, at least in part (unless circulation of such toxic compounds between killed and viable cells must be taken into account). Provided circulation does occur, it could not account for the increase of bactericidal capacity of $f_{s w}$, which was found to be correlated with rising numbers of inactivated tests bacteria. At present, these observations can best be interpreted according to the theory of nutrient-dependent antibacterial activity of sea water (Moesus 1972b) which, in principle, also is applicable to all other findings reported in this paper. This theory is based on the observation of great differences in inactivation of test bacteria at various nutrient concentrations below about $10^{-4} \mathrm{mg} / \mathrm{ml}$ of organic matter. Two critical nutrient concentrations causing maximum inactivation efficacy of sea water were found. Therefore, depending on the initially present food level, reduction or enhancement of the nutrient concentration results either in increased or decreased test bacterial kill.

Lysis of inactivated test bacteria certainly brings about nutrient enrichment of sea water. This statement is supported by the establishment of fairly constant numbers of colony-forming marine bacteria/ml during incubation of successive inocula in rsw (Fig. 1), suggesting continuous supply of nutrients. Otherwise - after the initial increase - a drop in bacterial number/ml should have occurred, as usual, during longterm incubation of $r s w$. Hence the stronger inactivation of successive inocula of $E s c h e-$ richia coli and Stapbylococcus aureus in $f$ sw is attributed to a gradual increase in the nutrient concentration available for each inoculum. Seemingly, this conclusion is contradicted by the findings obtained from repeatedly inoculated asw (Fig. 2), since in this medium the assumed increase of the food level resulted in decreased antibacterial activity. However, the difference between the results obtained must be ascribed to the influence of autoclaving which causes destruction of possibly present bactericides and produces precipitation of inorganic compounds. The precipitates contain considerable portions of heavy metals present in sea water, which are thought to be an important factor in bactericidal capacity (JoNEs 1964, 1967). Hence it is assumed that the decrease in antibacterial activity of asw was due mainly to reduced amounts of inimical constituents of sea water.

In rsw the effect of killed test bacteria on antibacterial capacity is superimposed by activities of marine bacteria. This becomes obvious by comparing the findings presented in Figures 1 and 2. During the experiment in question considerable variations in inactivation of successive inocula in rsw were found. The observation made on the second inoculum of Stapbylococcus aureus strictly contradicts possible effects of inimical compounds released by marine bacteria during incubation of the first inoculum. This finding is of special interest, since this strain was often inactivated more rapidly in fsw than in rsw (Moebus 1972a, c). Most probably, beneficial effects of marine bacterial activities in $r s w$ are responsible for such findings. Results obtained for second 
inocula of Escherichia coli and Serratia marinorubra also are peculiar in that, despite initially increased inactivation rates, nearly the same kill was attained finally as had been found for the first inocula. If bactericides, produced by marine bacteria during the first incubation period, were responsible for the initially accelerated inactivation of the second inocula, the reduced kill, observed after more than 2 days of incubation, would indicate that harmful substances were used up for the most part at that time. The results found for the third inoculum of $E$. coli agree with such an assumption since its inactivation was reduced initially. However, the findings obtained for S. marinorubra cannot be explained in this way. The nearly identical inactivation curves found for inocula 2 and 3 of this strain may be due to the maintenance of the same nutrient level during strong inactivation of large numbers of cells $/ \mathrm{ml}$, until attainment of a higher nutrient concentration/viable cell which caused reduced bacterial kill/unit time.

The involvement of bactericidal excretes of marine bacteria is contradicted also by stronger inactivation of Escherichia coli and Stapbylococcus aureus in fsw than in rsw (Figs. 3, 4 and 5). It should be noted that such observations were made more frequently during tests performed at enlarged surface/volume ratios, i. e. in correlation with accelerated marine bacterial growth, than under standard conditions. It is assumed that, at least during the respective experiments, nutrient consumption by marine bacteria was more important than release of inimical products. However, according to the theory of nutrient-dependent antibacterial activity of sea water (Moebus 1972b), this assumption also may hold true in regard to experiments during which inactivation was stronger in $r s w$ than in $f s w$. The important role of competitive food consumption is especially supported by findings obtained for Serratia marinorubra. This strain was inactivated to considerable degrees in rsw only; but its survival in this medium was never negatively affected by marine bacterial growth intensified at increased surface/volume ratios. The other results obtained during the investigation of solid-surface effects on inactivation of test bacteria also can be interpreted according to the above mentioned theory.

In general, a dominant importance of harmful metabolic by-products of marine bacteria is questioned by the present results. Considerable variations in the influence of indigenous populations on inactivation of test bacteria in rsw must be expected, due to changes in predominant bacterial species as well as to differences in nature and concentration of the nutrients present. This statement is supported by this investigation and by results of experiments performed with pure cultures of marine bacteria in sea water, sampled at different seasons. These problems are still under investigation.

\section{SUMMARY}

1. The antibacterial activity of raw sea water varied considerably during incubation of successive inocula of Eschericbia coli, Staphylococcus aureus, and Serratia marinorubra. In most cases inactivation of second inocula was stronger than that of first ones. However, with $S$. aureus, contradictory results were obtained also.

2. The bactericidal effect of filter-sterilized sea water was strengthened by inactivated 
cells of Escherichia coli and Stapbylococcus aureus. Contradictory findings were obtained from autoclaved sea water.

3. Inactivation of test bacteria was greatly influenced by solid surfaces. In most cases, the kill of Escherichia coli and Staphylococcus aureus in raw and sterile-filtered sea water was stronger at increased surface/volume ratios than under standard conditions. More rapid inactivation of these test strains in sterile-filtered, than in raw, sea water occurred more often at enlarged ratios of solid surface per unit volume. The survival of Serratia marinorubra was positively affected by solid surfaces.

4. It is concluded that changes in nutritive conditions occurring during the experiments are more important in regard to antibacterial activity of sea water than production of harmful matter by marine bacteria.

Acknowledgements. This investigation was supported by a grant of the Deutsche Forschungsgemeinschaft, and by the Biologische Anstalt Helgoland. Critical reading of this manuscript by Dr. W. GuNKEL is greatfully acknowledged. Thanks are extended to Mr. J. Nitsche for assistance.

\section{LITERATURE CITED}

Aubert, M., Aubert, J. \& Gauthier, M., 1968. Pouvoir autoepurateur de l'eau de mer et substances antibiotiques produites par les organismes marins. Revue int. Océanogr. méd. 10, $137-207$.

BaAm, R. B., Gandhr, N. M. \& Frettas, Y. M., 1966. Antibiotic activity of marine microorganisms. Helgoländer wiss. Meeresunters. 13, 181-187.

Carlucci, A. F. \& Pramer, D., 1960. An evaluation of factors affecting the survival of Escherichia coli in sea water. II. Salinity, pH, and nutrients. Appl. Microbiol. 8, 247-250.

GAUTHIER, M., 1969. Substances antibactériennes produites par les bactéries marines. I. Etude systématique de l'activité antagoniste de soudes bactériennes marines vis-à-vis de germes telluriques aérobies. Revue int. Océanogr. méd. 15/16, 41-60.

GIAXA, DE, 1889. Über das Verhalten einiger pathogener Mikroorganismen im Meerwasser. Z. Hyg. InfektKrankh. 6, 162-225.

Grein, A. \& MeYers, S. P., 1958. Growth characteristics and antibiotic production of actinomycetes isolated from littoral sediments and materials suspended in sea water. J. Bact. $\mathbf{7 6}$, $457-463$.

Heukelexian, H. \& Heller, A., 1940. Relation between food concentration and surface for bacterial growth. J. Bact. 40, 547-558.

JoNEs, G. E., 1964. Effect of chelating agents on the growth of Escherichia coli in sea water. J. Bact. 87, 483-499.

- 1967. Precipitates from autoclaved sea water. Limnol. Oceanogr. 12, 165-167.

Ketchum, B. H, Carey, C. L. \& Brrges, M. P., 1949. Preliminary studies on the viability and dispersal of coliform bacteria in the sea. In: Limnological aspects of water supply and waste disposal. Am. Assn. Adv. Sci., Washington, D. C., 64-73.

Krasilnirova, E. N., 1961. Antibiotic properties of microorganisms isolated from various depth of world oceans. Milkrobiologiya 30, 651-657.

Morbus, K., 1972a. Seasonal changes in antibacterial activity of North Sea water. Mar. Biol. 13, 1-13.

- 1972b. Bactericidal properties of natural and synthetic sea water as influenced by addition of low amounts of organic matter. Mar. Biol. 15, 81-88.

- 1972c. Studies on the influence of plankton on antibacterial activity of sea water. Helgoländer wiss. Meeresunters. 23, 127-140. 
Rosenfeld, W. D. \& Zobeli, C. E., 1947. Antibiotic production by marine organisms. J. Bact. 54, 393-398.

Sieburth, J. M., 1968. The influence of algal antibiosis on the ecology of marine microorganisms. In: Advances in Microbiology of the sea. Ed. by M. R. Droop \& E. J. F. Woop. Acad. Press, New York, 1, 63-94.

STARK, W. H., StadLER, J. \& McCoy, E., 1938. Some factors affecting the bacterial population of freshwater lakes. J. Bact. 36, 653-654.

Vaccaro, R. F., Briggs, M. P., Carey, C. L. \& Ketchum, B. H., 1950. Viability of Escherichia coli in sea water. Am. J. publ. Hlth 40, 1257-1266.

Zobel., C. E., 1943. The effect of solid surfaces upon bacterial activity. J. Bact. 46, 39-56.

- \& ANDerson, D. Q., 1936. Observations on the multiplication of bacteria in different volumes of stored sea water and the influence of oxygen tension and solid surfaces. Biol. Bull. mar. biol. Lab., Woods Hole 71, 324-342.

- \& UPHAM, H. C., 1944. A list of marine bacteria including descriptions of sixty new species. Bull. Scripps Instn Oceanogr. 5, 239-292.

Author's address: Dr. K. Moebus

c/o Graduate School of Oceanography

University of Rhode Island

Narragansett Bay Campus

Kingston, R.I. 02881

USA 